\title{
A new monolithic Pt-Pd-Rh motorcycle exhaust catalyst to meet future emission standards
}

\author{
Suning Wang a, Yajuan Cui b, Li Lan ${ }^{\text {b }}$, Zhonghua Shi ${ }^{\text {b , Ming Zhao }}{ }^{\text {, }}$ Maochu Gong ${ }^{\mathrm{b}}$, Ruimei Fang a, \\ Sijie Chen ${ }^{b}$, Yaoqiang Chen ${ }^{\mathrm{a}, \mathrm{b}, *}$ \\ a College of Chemical Engineering, Sichuan University, Chengdu 610064, Sichuan, China \\ ${ }^{\mathrm{b}}$ Key Laboratory of Green Chemistry \& Technology of Ministry of Education, College of Chemistry, Sichuan University, Chengdu 610064, Sichuan, China
}

\section{A R T I C L E I N F 0}

\section{Article history:}

Received 26 January 2014

Accepted 21 March 2014

Published 20 September 2014

Keywords:

Motorcycle exhaust purification

Monolithic catalyst

Pt-Pd-Rh

Air-to-fuel ratio characteristic

Space velocity characteristic

Temperature characteristic

\begin{abstract}
A B S T R A C T
A new composite oxide material as support, $\mathrm{CeO}_{2}-\mathrm{ZrO}_{2}-\mathrm{La}_{2} \mathrm{O}_{3}-\mathrm{PrO}_{2}-\mathrm{Al}_{2} \mathrm{O}_{3}$, was synthesized by a co-precipitation method. Pd-Rh, Pt-Rh, and Pt-Pd-Rh supported on monolithic carrier catalysts were obtained by an impregnation route. The textural, structural, and reductive properties of the catalysts were characterized by $\mathrm{N}_{2}$ adsorption-desorption, temperature-programmed reduction, oxygen storage capacity measurements, and X-ray diffraction. The air-fuel-ratio (A/F), space velocity (SV), and temperature characteristics of the fresh and aged catalysts were investigated on a systematic basis. The results showed that among the three catalysts, Pt-Pd-Rh displayed the best performance. For an SV of $40000 \mathrm{~h}^{-1}$ in the case of fresh Pt-Pd-Rh, the light-off temperatures $\left(T_{50}\right)$ for $\mathrm{C}_{3} \mathrm{H}_{8}, \mathrm{CO}$, and NO were 239,187 , and $191^{\circ} \mathrm{C}$, respectively, with corresponding $\Delta T\left(T_{90}-T_{50}\right)$ values of 21,3 , and $3{ }^{\circ} \mathrm{C}$, respectively. After aging, the $T_{50}$ for $\mathrm{C}_{3} \mathrm{H}_{8}, \mathrm{CO}$, and NO were 298,203 , and $223{ }^{\circ} \mathrm{C}$, respectively, and the $\Delta T$ values were 22,5 , and $13{ }^{\circ} \mathrm{C}$, respectively. Moreover, the window widths for the $\mathrm{A} / \mathrm{F}$ in the case of fresh and aged Pt-Pd-Rh catalysts were wide. Overall, the excellent performance for the Pt-Pd-Rh catalyst makes it suitable as a motorcycle exhaust catalyst, which can meet future emission standards.
\end{abstract}

(C) 2014, Dalian Institute of Chemical Physics, Chinese Academy of Sciences. Published by Elsevier B.V. All rights reserved.

\section{Introduction}

In 2010, the annual output and ownership of motorcycles in China were 25 million and 100 million units, accounting for more than $40 \%$ and $50 \%$ of those in the world [1], respectively, indicating that China has become the largest producer and consumer in the world for motorcycles. According to statistics, motorcycle exhaust emissions of hydrocarbons (HC), CO, and $\mathrm{NO}_{x}$ amounted to 7.48 million tons in China for the year 2011 [2]. What is more, in comparison with cars fueled by gasoline and diesel, the exhaust gases of motorcycles contain large proportions of small particles $(\sim 0.04 \mu \mathrm{m})$ within the PM 2.5 frac- tion, which are harmful to health. Therefore, it is imperative to reduce the emissions of the hazardous components in motorcycle exhaust gas $[3,4]$. On July 1,2008 , China began to implement the third stage of motorcycle emission standards [5], and the fourth stage, which is in the process of being drafted, will be stricter [6,7]. In addition, although electric fuel injection technology will be applied in motorcycles, there are still many technical challenges, such as major fluctuations in the air-fuelratio $(\mathrm{A} / \mathrm{F})$ and working conditions of high temperature and space velocity (SV) when compared with cars fueled by gasoline [8]. Therefore, it is critical to improve the performance of catalysts to meet future motorcycle emission standards.

*Corresponding author. Tel/Fax: +86-28-85418451; E-mail: nic7501@scu.edu.cn This work was supported by the National Natural Science Foundation of China $(20803049,21173153)$. 
The support materials used in motorcycle exhaust gas catalysts typically consist of $\mathrm{CeO}_{2}-\mathrm{ZrO}_{2}$ oxides and $\mathrm{Al}_{2} \mathrm{O}_{3}$. The $\mathrm{CeO}_{2}-\mathrm{ZrO}_{2}$ solid solution has good oxygen storage capability (OSC) and has merit in promoting a water gas shift reaction, but its resistance to aging and durability is relatively poor [9-11]. $\mathrm{Al}_{2} \mathrm{O}_{3}$, however, possesses high specific surface area, large pore volume, and remarkable anti-aging performance [12,13]. According to Morikawa et al. [14], a modified Ce-Zr rare earth oxygen storage material (OSM) combined with $\mathrm{Al}_{2} \mathrm{O}_{3}$ exhibits good oxygen storage capability. Furthermore, $\mathrm{Al}_{2} \mathrm{O}_{3}$ has played an important role as a "diffusion barrier", inhibiting the aggregation of Ce-Zr materials and precious metals during the sintering process. Transition and rare earth elements could be doped into ceria-based oxides to change their phase structure to improve oxygen transmission at low temperature and realize high thermal stability [15-17]. In addition, the active components of motorcycle exhaust gas catalysts are usually based on $\mathrm{Pt}, \mathrm{Pd}$, and Rh, specifically Pd itself or Pd-Rh, Pt-Rh, and Pt-Pd-Rh [18].

To exploit the key advantages of OSM and $\mathrm{Al}_{2} \mathrm{O}_{3}$ and further improve the performance of support materials by addition of rare earth elements, a new composite oxide, $\mathrm{CeO}_{2}-\mathrm{ZrO}_{2}-\mathrm{La}_{2} \mathrm{O}_{3}$ $\mathrm{PrO}_{2}-\mathrm{Al}_{2} \mathrm{O}_{3}$, was synthesized by a co-precipitation method, and the Pd-Rh, Pt-Rh, and Pt-Pd-Rh supported on monolithic carrier catalysts were obtained by an impregnation route. Then the $\mathrm{A} / \mathrm{F}, \mathrm{SV}$, and temperature characteristic of the catalysts before and after aging were investigated in a systematic manner. The results demonstrated that the new catalysts were suitable for motorcycle exhaust gas treatment, with the excellent performance characteristics meeting future emission standards.

\section{Experimental}

\subsection{Preparation of catalysts}

The composite oxide, $\mathrm{CeO}_{2}-\mathrm{ZrO}_{2}-\mathrm{La}_{2} \mathrm{O}_{3}-\mathrm{PrO}_{2}-\mathrm{Al}_{2} \mathrm{O}_{3}$, was prepared by a co-precipitation method. An aqueous solution of $\mathrm{Ce}\left(\mathrm{NO}_{3}\right)_{3} \cdot 6 \mathrm{H}_{2} \mathrm{O}, \mathrm{La}\left(\mathrm{NO}_{3}\right)_{3} \cdot 6 \mathrm{H}_{2} \mathrm{O}, \operatorname{Pr}\left(\mathrm{NO}_{3}\right)_{3} \cdot 6 \mathrm{H}_{2} \mathrm{O}$ and $\mathrm{Al}\left(\mathrm{NO}_{3}\right)_{3} \cdot$ $9 \mathrm{H}_{2} \mathrm{O}$ was first mixed with $\mathrm{ZrO}\left(\mathrm{CO}_{3}\right) \cdot 6 \mathrm{H}_{2} \mathrm{O}$ dissolved in concentrated $\mathrm{HNO}_{3}$. The resulting mixed solution was injected into a reactor. At the same time, a buffer solution of $\mathrm{NH}_{3} \cdot \mathrm{H}_{2} \mathrm{O}$ and $\left(\mathrm{NH}_{4}\right)_{2} \mathrm{CO}_{3}$ in excess was added to the reactor. The $\mathrm{pH}(\mathrm{pH}=9)$, reaction temperature, and stirring speed in the reactor were carefully controlled during the process. The obtained precursors were aged at $90^{\circ} \mathrm{C}$ for $4 \mathrm{~h}$, then filtered and washed with distilled water until no change in $\mathrm{pH}$ could be detected. The precipitates were dried at $70{ }^{\circ} \mathrm{C}$, heated at $600{ }^{\circ} \mathrm{C}$ for $3 \mathrm{~h}$, and then calcined at $900{ }^{\circ} \mathrm{C}$ for $5 \mathrm{~h}$. The synthesized sample $\mathrm{CeO}_{2}-\mathrm{ZrO}_{2}-\mathrm{La}_{2} \mathrm{O}_{3}-\mathrm{PrO}_{2}-\mathrm{Al}_{2} \mathrm{O}_{3}$ (mass ratio 30:10:5:5:50) was marked as CZLPA.

Pt, Pd, and Rh were loaded on CZLPA by an impregnation method using solutions of $\mathrm{Pd}\left(\mathrm{NO}_{3}\right)_{2}, \mathrm{Pt}\left(\mathrm{NO}_{3}\right)_{4}$, and $\mathrm{RhCl}_{3}$ as the metal precursors, respectively. After drying, Pd/CZLPA, Pt/CZLPA, and Rh/CZLPA catalyst powders were obtained. The resulting catalyst powders, Pd/CZLPA and Rh/CZLPA, Pt/CZLPA and Rh/CZLPA, and Pd/CZLPA, Pt/CZLPA, and $\mathrm{Rh} / \mathrm{CZLPA}$, were mixed in specific proportions, respectively.
Then distilled water was added to each mixture, and homogeneous slurries were obtained by ball mill. The slurries were spread on a honeycomb cordierite $\left(2.5 \mathrm{~cm}^{3}\right.$, Corning, USA; coating amount $160 \mathrm{~g} / \mathrm{L})$. The fresh monolithic catalysts, Pd-Rh $(\mathrm{Pd} / \mathrm{Rh}=10 / 1), \mathrm{Pt}-\mathrm{Rh}(\mathrm{Pt} / \mathrm{Rh}=10 / 1)$, and Pt-Pd-Rh $(\mathrm{Pt} / \mathrm{Pd} / \mathrm{Rh}$ $=3 / 7 / 1$ ), were obtained after drying and calcining at $550{ }^{\circ} \mathrm{C}$ for $3 \mathrm{~h}$ and were labeled as Cat1f, Cat2f, and Cat3f, respectively. The amount of precious metal coating in each catalyst was 1.76 $\mathrm{g} / \mathrm{L}$. These fresh catalysts were next thermally aged at $1000{ }^{\circ} \mathrm{C}$ for $5 \mathrm{~h}$ in air and labeled as Cat1a, Cat2a, and Cat3a.

\subsection{Characterization of catalysts}

The textural properties of the catalysts were obtained by the $\mathrm{N}_{2}$ adsorption-desorption method on a Quantachrome SI instrument. The specific surface area, pore volume, and pore size distribution of the catalyst powders were measured at $-196^{\circ} \mathrm{C}$. Prior to each measurement, the catalyst powders were degassed at $300{ }^{\circ} \mathrm{C}$ for $3 \mathrm{~h}$ under vacuum.

Temperature-programmed reduction in $\mathrm{H}_{2}\left(\mathrm{H}_{2}\right.$-TPR) was carried out in a quartz tubular micro-reactor equipped with a thermal conductivity detector. Prior to analysis, the catalyst powders (100 $\mathrm{mg}$ ) were pre-cleaned using $\mathrm{N}_{2}(20 \mathrm{~mL} / \mathrm{min})$ with temperature cycling from room temperature to $450{ }^{\circ} \mathrm{C}$, holding at this temperature for $50 \mathrm{~min}$ and then cooling to room temperature. Measurements were performed from room temperature to $600{ }^{\circ} \mathrm{C}$ in $5 \% \mathrm{H}_{2}-95 \% \mathrm{~N}_{2}(20 \mathrm{~mL} / \mathrm{min})$ at a heating rate of $8^{\circ} \mathrm{C} / \mathrm{min}$.

OSC was performed in a purpose-built experimental device. Catalyst powders (200 mg) were reduced in pure $\mathrm{H}_{2}$ (40 $\mathrm{mL} / \mathrm{min}$ ) as the temperature was raised from room temperature to $550{ }^{\circ} \mathrm{C}$ before measurement of OSC. Then the powders were maintained at this temperature for $60 \mathrm{~min}$, cooled to 200 ${ }^{\circ} \mathrm{C}$, and purged with pure He $(20 \mathrm{~mL} / \mathrm{min})$. The OSC was measured by injecting discrete oxygen pulses into the sample bed until no further oxygen consumption was detected by TCD.

X-ray diffraction (XRD) patterns were recorded using a Rigaku D/max-rA diffractometer with $\mathrm{Cu} K_{\alpha}$ radiation $(40 \mathrm{kV}$, $25 \mathrm{~mA}, \lambda=0.15406 \mathrm{~nm}$ ). The powders were scanned within the $2 \theta$ range of $10^{\circ}$ to $80^{\circ}$. The crystalline phases were identified by comparing them with reference data from the International Centre for Diffraction Data (ICDD).

\subsection{Performance evaluation of catalysts}

The performance of the catalysts was evaluated in a multiple fixed-bed continuum flow micro-reactor with a gas mixture that simulated the exhaust from a motorcycle. First, the catalysts were pretreated under a reaction atmosphere at $550{ }^{\circ} \mathrm{C}$ for $1 \mathrm{~h}$. Then activity was evaluated by cooling to the reaction temperature. The $\mathrm{A} / \mathrm{F}$ characteristics were evaluated at $400{ }^{\circ} \mathrm{C}$ with an SV of $40000 \mathrm{~h}^{-1}$; the SV properties were evaluated at $400{ }^{\circ} \mathrm{C}$ and the space velocity of 20000,40000 , and $60000 \mathrm{~h}^{-1}$; the temperature characteristics were evaluated at an $\mathrm{SV}$ of $40000 \mathrm{~h}^{-1}$. The composition of reaction gas was $0.045 \% \mathrm{C}_{3} \mathrm{H}_{8}$, $1.5 \% \mathrm{CO}, 0.11 \% \mathrm{NO}, 10 \% \mathrm{H}_{2} \mathrm{O}, 10 \% \mathrm{CO}_{2}$, different levels of $\mathrm{O}_{2}$, and $\mathrm{N}_{2}$ as balance. The contents of $\mathrm{C}_{3} \mathrm{H}_{8}, \mathrm{CO}$, and $\mathrm{NO}$ in the 
stimulated gas before and after reaction were analyzed using an FGA-4100 five-component analyzer (Foshan Analysis Instrument Co., Ltd., China), and then the conversion for each composition was calculated.

\section{Results and discussion}

\subsection{Textural properties of catalysts}

Table 1 shows the textural parameters for fresh and aged catalysts. It can be seen that the textural properties of these catalysts are similar to each other. Compared with the fresh catalysts, the surface area and pore volume of aged catalysts decreased; also the average pore radius of aged catalysts increased, indicating the formation of bigger pores caused by sintering and collapse during the aging process $[5,19]$. The surface areas of the catalysts after aging are still about $70 \mathrm{~m}^{2} / \mathrm{g}$, which is slightly higher than that of the literature $[14,20]$, demonstrating that the catalysts prepared in this study have excellent age resistance and are suitable for the high-temperature environment of motorcycle exhausts.

Figure 1 shows the $\mathrm{N}_{2}$ adsorption-desorption isotherms and the pore radius distribution of the catalysts. The aperture radii of the fresh catalysts were about 4-8 $\mathrm{nm}$, and the shapes of the three isotherms are almost the same. They are typical of an irreversible type IV adsorption isotherm with a $\mathrm{H}_{2}$ hysteresis loop, indicating that the pores of the samples are slit and inkbottle-type mesopores. The larger the mesopores, the higher the pressure needed for capillary condensation to occur. Therefore, the extent of adsorption increases faster in the high-pressure regions, suggesting that the large pores are abundant [21,22], which is well suited to the high-speed environment of a motorcycle exhaust. After aging, the aperture radii are about 5-12 nm and the areas of hysteresis shrink, which further suggests the collapse of small pores after aging $[19,23]$. The hysteresis loops for Pd-Rh and Pt-Rh catalysts are closed at a relative pressure $\left(p / p_{0}\right)$ of about 0.8 , which is about $23 \%$ higher than fresh catalysts. By comparison, the hysteresis loops for the Pt-Pd-Rh catalyst are closed at $p / p_{0} \approx 0.7$, which only increased by $7.7 \%$ compared with the fresh catalyst. This result demonstrated that the extent of collapse for Pt-Pd-Rh is significantly less than that for Pd-Rh and Pt-Rh; also, the durability at high temperature is enhanced for the Pt-Pd-Rh catalyst [23].

\section{2. $H_{2}$-TPR study}

Figure 2 displays $\mathrm{H}_{2}$-TPR profiles of the fresh and aged cat-

Table 1

Textural parameters of the fresh and aged catalysts.

\begin{tabular}{lccc}
\hline Sample & $\begin{array}{c}\text { Surface area } \\
\left(\mathrm{m}^{2} / \mathrm{g}\right)\end{array}$ & $\begin{array}{c}\text { Pore volume } \\
(\mathrm{mL} / \mathrm{g})\end{array}$ & $\begin{array}{c}\text { Average pore } \\
\text { radius }(\mathrm{nm})\end{array}$ \\
\hline Cat1f & 131 & 0.36 & 5.46 \\
Cat2f & 123 & 0.36 & 5.76 \\
Cat3f & 130 & 0.36 & 5.58 \\
Cat1a & 74 & 0.31 & 8.32 \\
Cat2a & 69 & 0.32 & 9.15 \\
Cat3a & 75 & 0.34 & 9.04 \\
\hline
\end{tabular}
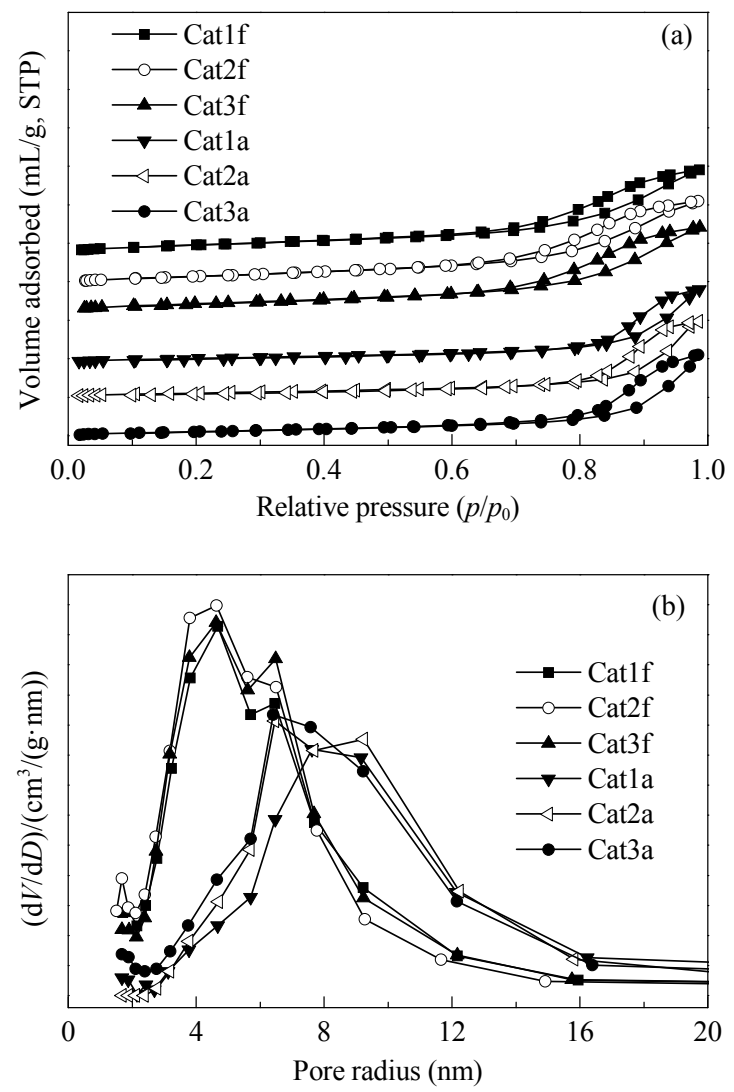

Fig. 1. $\mathrm{N}_{2}$ adsorption-desorption isotherms (a) and pore size distribution (b) of the fresh and aged catalysts.

alysts. All the fresh and aged catalysts feature dominant broad peaks below $400{ }^{\circ} \mathrm{C}$, which are attributed to the reduction of $\mathrm{Pt}$, $\mathrm{Pd}$, and $\mathrm{Rh}$, and these reduction temperatures are lower than those reported in the literature [24-27], indicating that the catalysts possess superior reductive properties. The peak area responses for the aged catalysts are suppressed relative to the fresh ones, which is due to substantial agglomeration of noble metals and shrinkage of the specific surface area and pore volume. A consequence of this is that a portion of the precious metal species are entrapped, leading to a reduction in the reduced species such that the peak area responses are decreased

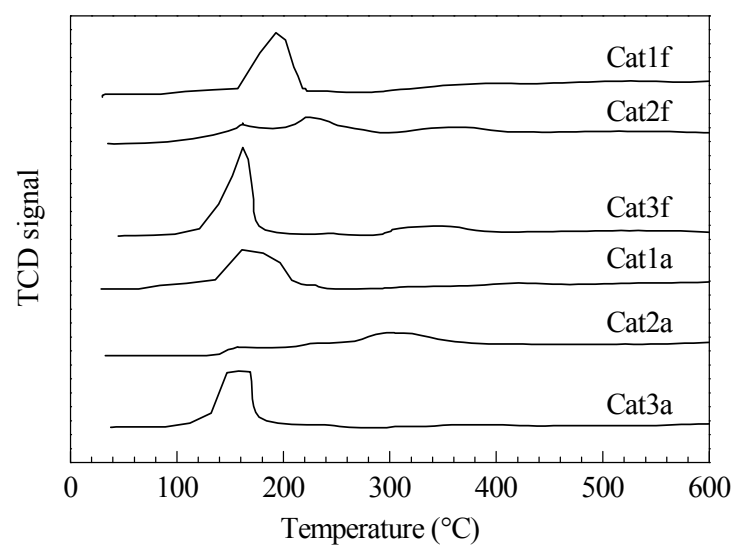

Fig. 2. $\mathrm{H}_{2}$-TPR profiles of the fresh and aged catalysts. 
$[21,28]$. The reduction in peak areas for the catalysts before and after aging follow the sequence Pt-Pd-Rh $>\mathrm{Pd}-\mathrm{Rh}>\mathrm{Pt}-\mathrm{Rh}$, indicating that Pt-Pd-Rh exhibits the best reducibility.

\subsection{OSC measurements}

The OSC of the catalysts before and after aging are shown in Fig. 3. The OSCs of aged samples are lower than that of fresh ones primarily because of the sintering of the support materials and agglomeration of the precious metals [14,27]. The OSC of $\mathrm{Pt}-\mathrm{Pd}-\mathrm{Rh}$ is the highest and that of Pt-Rh is the lowest, which may reflect the different combining capacities between the precious metals and the support materials, as well as differing synergistic effects among the noble metals [28]. This result indicated that the Pt-Pd-Rh catalyst is responsive to larger fluctuations in the $\mathrm{A} / \mathrm{F}$ and the long-term high-temperature environment of the motorcycle exhaust.

\subsection{XRD measurements}

XRD patterns for the catalysts before and after aging are illustrated in Fig. 4. It can be seen that all the catalysts have a typical cubic $\mathrm{Ce}_{0.75} \mathrm{Zr}_{0.25} \mathrm{O}_{2}$ phase and an $\mathrm{Fm}-3 \mathrm{~m}$ space group. In contrast to the standard spectrum of $\mathrm{Ce}_{0.75} \mathrm{Zr}_{0.25} \mathrm{O}_{2}$, however, the characteristic diffraction peaks slightly shift to a lower $2 \theta$ degree, which is due to the doped rare earth elements, $\mathrm{La}\left(\gamma_{\mathrm{La}^{3+}}\right.$ $=0.106 \mathrm{~nm})$ and $\operatorname{Pr}\left(\gamma_{\mathrm{Pr}^{3+}}=0.101 \mathrm{~nm}, \gamma_{\mathrm{Pr}^{4+}}=0.09 \mathrm{~nm}\right)$ with the larger atomic radius entering the $\mathrm{Ce}_{0.75} \mathrm{Zr}_{0.25} \mathrm{O}_{2}\left(\gamma_{\mathrm{Ce}}{ }^{4+}=0.097\right.$ $\left.\mathrm{nm}, \gamma_{\mathrm{Zr}^{4+}}=0.084 \mathrm{~nm}\right)$ crystal lattice $[17,22]$. After aging, the diffraction peaks become sharper and more intense, and diffraction peaks for $\gamma-\mathrm{Al}_{2} \mathrm{O}_{3}$ are observed, indicating that high-temperature treatment leads to grain growth and an ordered arrangement of the cations. As shown in Fig. 4(b), the characteristic diffraction peaks for the catalysts shift slightly to higher $2 \theta$ degree after aging. This may be due to the following reasons: (1) the migration of larger radius $\mathrm{La}^{3+}$ and $\mathrm{Pr}^{3+} / \mathrm{Pr}^{4+}$ cations from the bulk to the surface of the crystal, and (2) the transformation of $\mathrm{Ce}^{3+}\left(\gamma_{\mathrm{Ce}^{3+}}=0.114 \mathrm{~nm}\right)$ to $\mathrm{Ce}^{4+}$ during the high-temperature calcination process, resulting in shrinkage of the cell $[17,22,29,30]$.

The crystal size of the fresh and aged catalysts calculated according to the Scherrer equation is about 5.5-7.5 nm, which

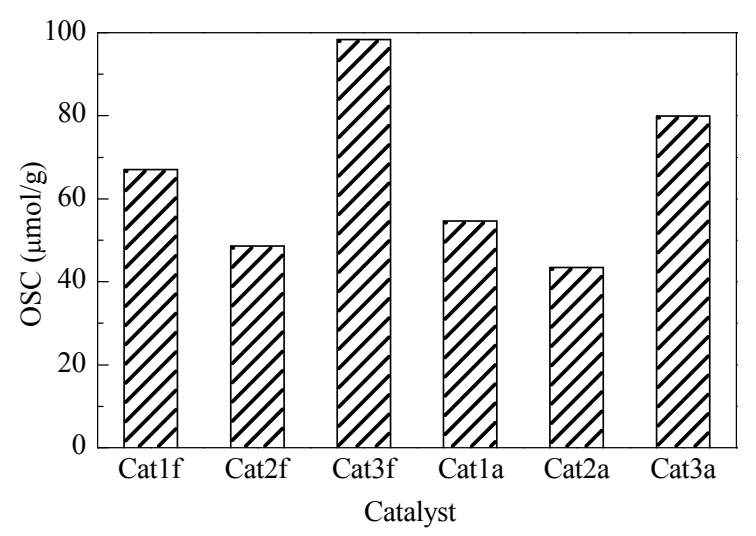

Fig. 3. OSC of the fresh and aged catalysts.
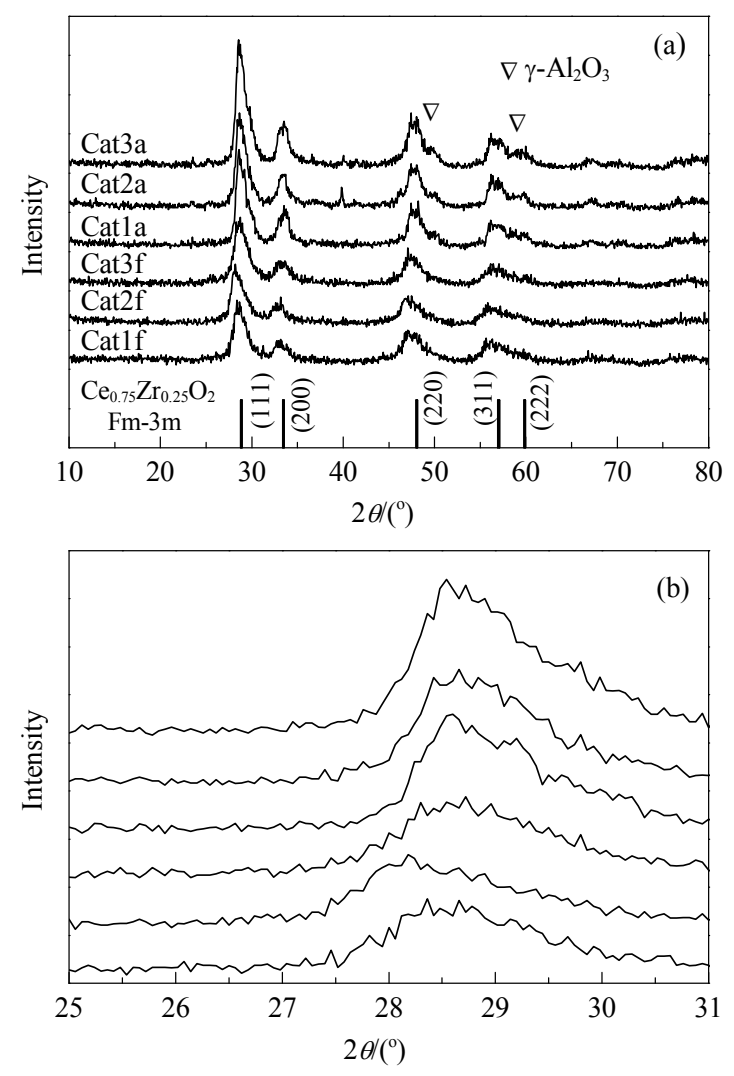

Fig. 4. XRD patterns of the fresh and aged catalysts.

implies little change of crystal size before and after aging, indicating excellent thermal stability of the catalysts. This phenomenon may benefit from $\mathrm{Al}_{2} \mathrm{O}_{3}$ acting as a "diffusion barrier", limiting the carrier materials' contact with each other. Thus, $\mathrm{Al}_{2} \mathrm{O}_{3}$ inhibits agglomeration of carrier material particles and, to a certain extent, increases the thermal stability of the materials $[14,31]$.

\subsection{Air-fuel-ratio of catalysts}

Figure 5 displays the A/F for the fresh and aged catalysts, which describes the relationships between the conversions of three kinds of fomites in the simulated motorcycle exhaust at the SV of $40000 \mathrm{~h}^{-1}$ and the A/F ( $S$ value). Figure 5(a) displays the properties of fresh catalysts. When $S<1$, NO undergoes full transformation for all the fresh catalysts, and the conversion for $\mathrm{CO}$ is $80 \%$. The performance of Pd-Rh and Pt-Pd-Rh for conversion of $\mathrm{C}_{3} \mathrm{H}_{8}$ is enhanced, which is due to $\mathrm{Pd}-\mathrm{Rh}$ and $\mathrm{Pt}-\mathrm{Pd}-\mathrm{Rh}$ facilitating the steam reformation reaction of $\mathrm{C}_{3} \mathrm{H}_{8}$ $[17,18,22]$. When $S>1$, there is complete conversion of CO, but the conversion of NO decreases significantly, and the window width of $\mathrm{NO}$ in the case of $\mathrm{Pd}-\mathrm{Rh}$ is the narrowest, owing to the conversion of NO being affected by the concentration of $\mathrm{O}_{2}$. With high concentrations of $\mathrm{O}_{2}$, the reduction of NO may be suppressed. In addition, the conversion of $\mathrm{C}_{3} \mathrm{H}_{8}$ over $\mathrm{Pt}-\mathrm{Rh}$ and Pt-Pd-Rh declines with increase of $S$, while the conversion of $\mathrm{C}_{3} \mathrm{H}_{8}$ over $\mathrm{Pd}-\mathrm{Rh}$ is still complete. This may reflect the fact that the coupling reactions of $\mathrm{C}_{3} \mathrm{H}_{8}$ and NO with Pt-Rh and Pt-Pd-Rh 

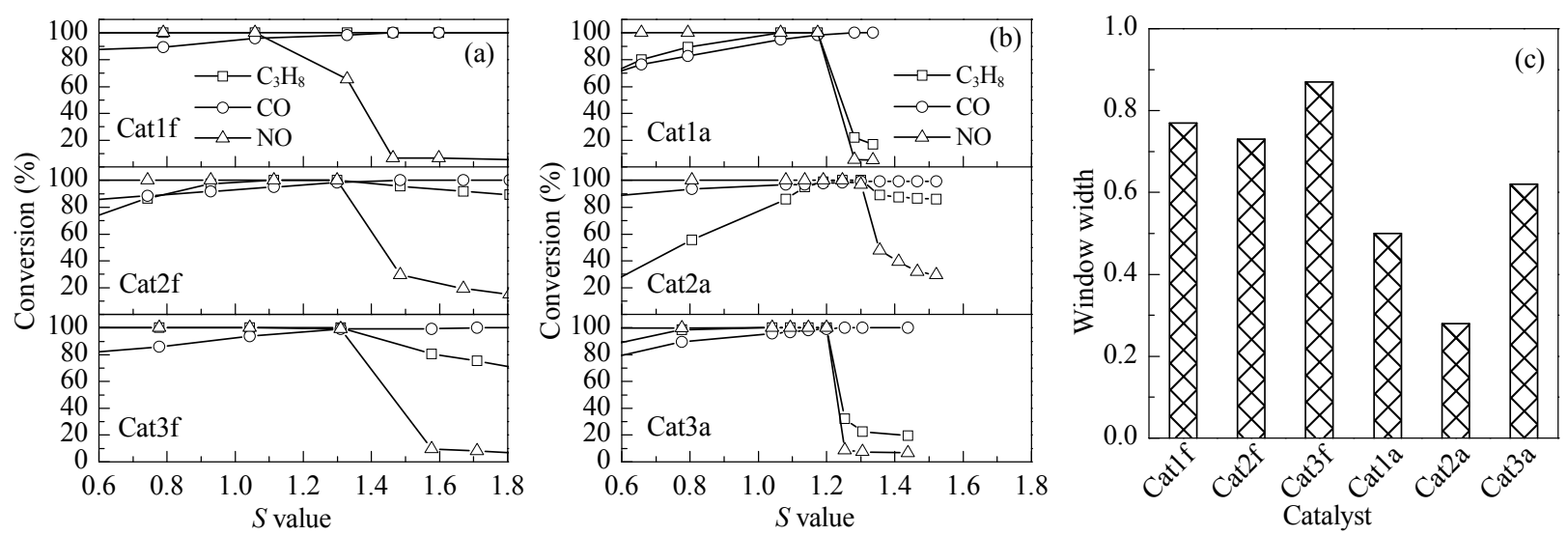

Fig. 5. Variations in the conversion of $\mathrm{C}_{3} \mathrm{H}_{8}, \mathrm{CO}$, and $\mathrm{NO}$ in simulated motorcycle exhaust at the space velocity of $40000 \mathrm{~h}^{-1}$ with air to fuel ratios $(S$ value) over the fresh (a) and aged (b) catalysts and window widths for the fresh and aged catalysts based on $80 \%$ conversion of the three pollutants (c).

are more efficient than that with Pd-Rh. The aged catalyst properties can be seen in Fig. 5(b), in which the catalytic properties of the three pollutants declined. The main reasons for this are the collapse of keyholes, a decrease in the specific surface areas, sintering of precious metals, and a reduction in active sites during the high-temperature treatment process $[19,27]$. These results are consistent with the textural properties of the aged catalysts. Figure 5(c) summarizes the window widths of the fresh and aged catalysts based on $80 \%$ conversion of the three pollutants at an SV of $40000 \mathrm{~h}^{-1}$. The window width for fresh catalysts follows the sequence Pt-Pd-Rh > $\mathrm{Pd}-\mathrm{Rh}>\mathrm{Pt}-\mathrm{Rh}$. After aging, the window widths for the catalysts decrease to different extents, the levels of decline being in the order Pt-Rh $>\mathrm{Pd}-\mathrm{Rh}>\mathrm{Pt}-\mathrm{Pd}-\mathrm{Rh}$, indicating that the Pt-Pd-Rh catalyst possesses an excellent $\mathrm{A} / \mathrm{F}$ property and good resistance to aging, which agrees with the TPR and OSC findings.

\subsection{Space velocity of catalysts}

Figure 6 reveals the window widths for fresh catalysts at the SV of 20000 and $60000 \mathrm{~h}^{-1}$. In conjunction with Fig. 5(a) and 5 (c), it can be seen that the windows become narrow when the SV increases. When the SV increases, the residence time for exhaust gas on the catalyst becomes shorter and mass transfer is restricted so that reactants have less time to enter the catalyst channels and react. Among the three catalysts, the windows for Pt-Pd-Rh at the SV of 20000, 40000, and $60000 \mathrm{~h}^{-1}$ are the widest, indicating that the Pt-Pd-Rh catalyst is well suited to the high-speed environment of motorcycle exhaust.

\subsection{Temperature characteristics of the catalysts}

Figure 7 shows the conversions for $\mathrm{C}_{3} \mathrm{H}_{8}, \mathrm{CO}$, and NO at different temperatures for fresh and aged catalysts in simulated motorcycle exhaust at an SV of $40000 \mathrm{~h}^{-1}$. The $T_{50}$ (conversion of $50 \%$ for specific reaction temperature), $T_{90}$ (conversion of $90 \%$ for specific reaction temperature), and $\Delta T\left(T_{90}-T_{50}\right)$ are listed in Table 2. The conversions for $\mathrm{C}_{3} \mathrm{H}_{8}, \mathrm{CO}$, and $\mathrm{NO}$ rise as the temperature increases, rapidly approaching complete conversion at high temperature. As a result of the high conversion of the saturated hydrocarbon over $\mathrm{Pt}$, the $T_{50}$ and $T_{90}$ values for $\mathrm{C}_{3} \mathrm{H}_{8}$ for the Pt-Rh catalyst are the lowest among that of the three catalysts [24,32]. After aging, owing to the sintering of the support materials and agglomeration of precious metals, the surface activity sites decline and the catalytic properties decrease [32,33]. Consequently, the $T_{50}, T_{90}$, and $\Delta T$ of the catalysts are higher, especially for the Pt-Rh catalyst. The $T_{50}$ and $T_{90}$ for $\mathrm{CO}$ and NO are relatively lower, which can be ascribed to
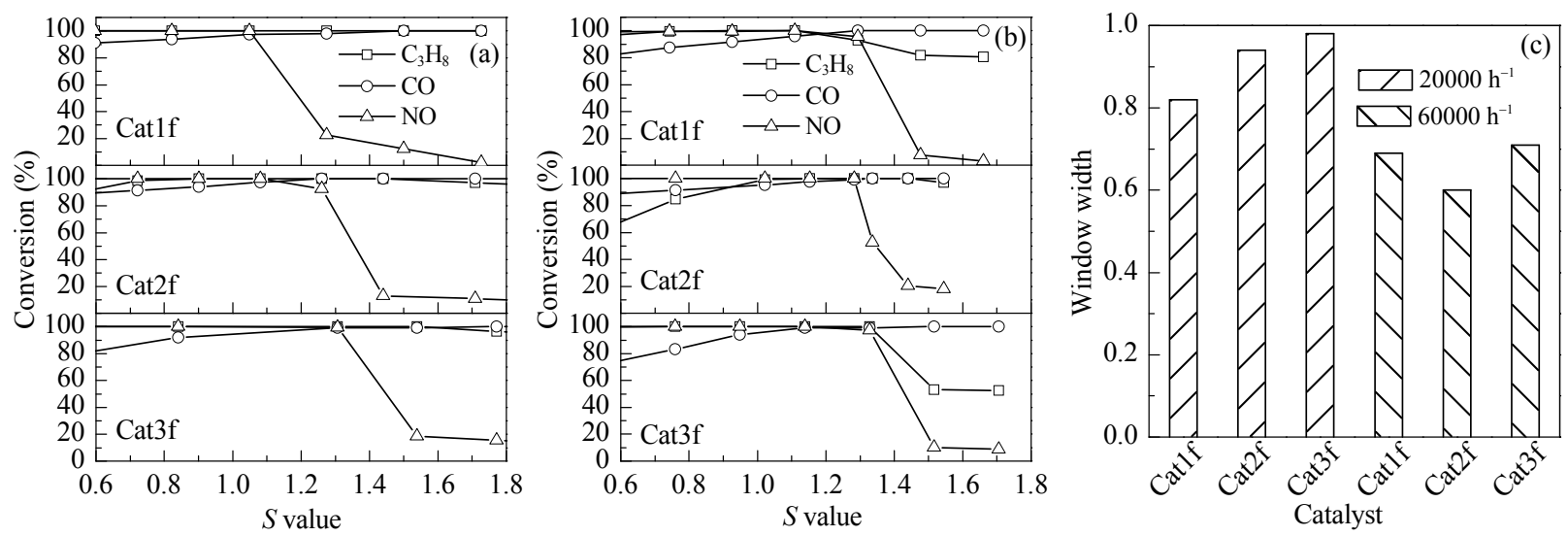

Fig. 6. Variations of air to fuel ratio (S value) windows over the fresh catalysts at the space velocities of $20000 \mathrm{~h}^{-1}(\mathrm{a})$ and $60000 \mathrm{~h}^{-1}$ (b), and the window widths for the fresh catalysts at different space velocities based on $80 \%$ conversions of the three pollutants (c). 

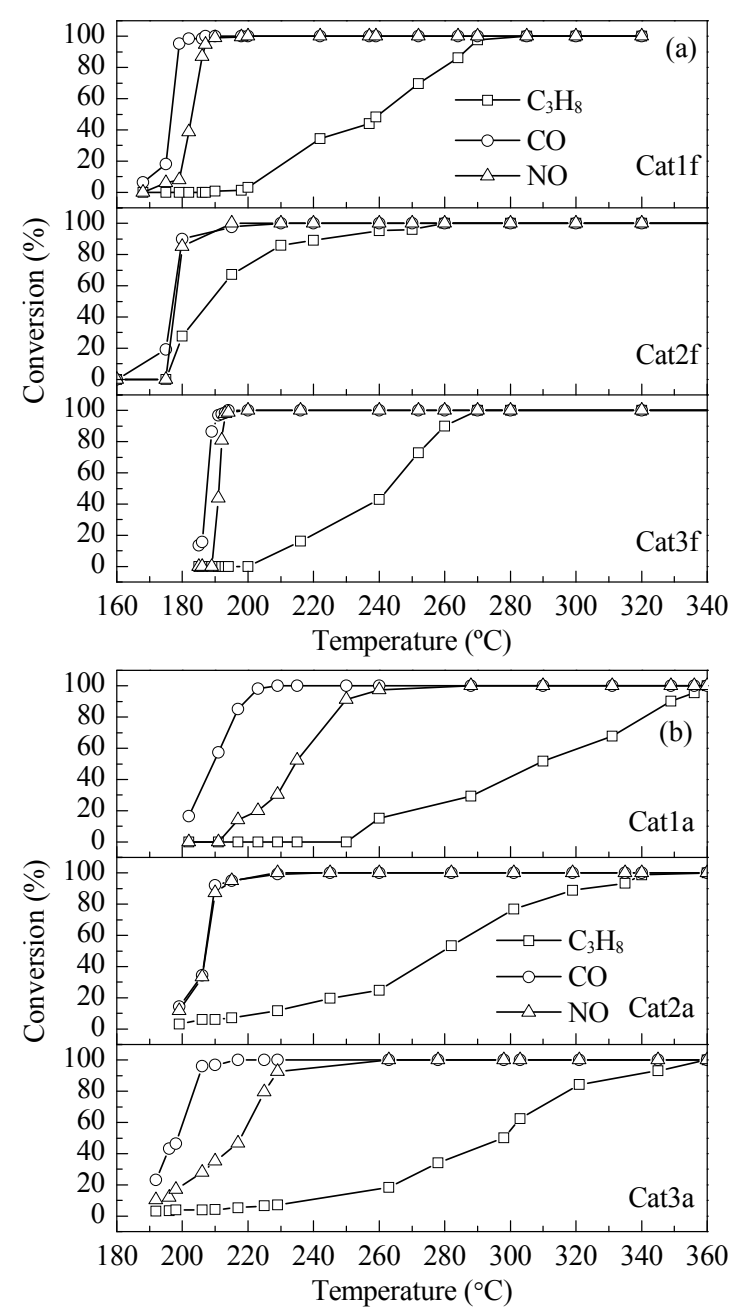

Fig. 7. $\mathrm{C}_{3} \mathrm{H}_{8}, \mathrm{CO}$, and $\mathrm{NO}$ conversions at different temperatures for the fresh (a) and aged (b) catalysts in simulated motorcycle exhaust at a space velocity of $40000 \mathrm{~h}^{-1}$.

Table 2

Light-off temperatures $\left(T_{50}\right)$, complete conversion temperatures $\left(T_{90}\right)$, and $\Delta T$ values for $\mathrm{C}_{3} \mathrm{H}_{8}, \mathrm{CO}$, and $\mathrm{NO}$ over the fresh and aged catalysts in simulated motorcycle exhaust at a space velocity of $40000 \mathrm{~h}^{-1}$.

\begin{tabular}{|c|c|c|c|c|c|c|c|c|c|}
\hline \multirow{2}{*}{ Catalys } & \multicolumn{3}{|c|}{$\mathrm{C}_{3} \mathrm{H}_{8}$} & \multicolumn{3}{|c|}{$\mathrm{CO}$} & \multicolumn{3}{|c|}{ NO } \\
\hline & $T_{50} /{ }^{\circ} \mathrm{C}$ & $\Gamma_{90} /{ }^{\circ} \mathrm{C}$ & $T /{ }^{\circ} \mathrm{C}$ & $T_{50} /{ }^{\circ} \mathrm{C}$ & $T_{90} /{ }^{\circ} \mathrm{C}$ & $T /{ }^{\circ} \mathrm{C}$ & $T_{50} /{ }^{\circ}$ & $T_{90} /{ }^{\circ} \mathrm{C}$ & $T /{ }^{\circ} \mathrm{C}$ \\
\hline Cat1f & 240 & 265 & 25 & 176 & 178 & 2 & 183 & 188 & 5 \\
\hline Cat2f & 190 & 220 & 30 & 178 & 180 & 2 & 178 & 181 & 2 \\
\hline Cat $3 \mathrm{f}$ & 239 & 260 & 21 & 187 & 190 & 3 & 191 & 194 & 3 \\
\hline at1a & 300 & 330 & 30 & 206 & 215 & 9 & 209 & 215 & 6 \\
\hline Cat2a & 298 & 346 & 48 & 227 & 231 & 4 & 231 & 239 & 8 \\
\hline Cat3a & 298 & 320 & 22 & 203 & 208 & 5 & 223 & 236 & 13 \\
\hline
\end{tabular}

the higher content of $\mathrm{CO}$ in the motorcycle exhaust compared with car fueled by gasoline. Once the CO ignites, the exhaust temperature rapidly increases, resulting in rapid and complete conversion of $\mathrm{CO}$ and NO. Moreover, the difference of $T_{50}$ between $\mathrm{CO}$ and NO is not clear, demonstrating a high degree of coupling between the two molecules. Considering the $T_{50}, T_{90}$ and $\Delta T$ data for the three pollutants before and after catalyst aging, the performance data for Pt-Pd-Rh is the most remarkable, particularly the results for the textural properties and the $\mathrm{H}_{2}$-TPR and OSC data.

\section{Conclusions}

A new composite oxide, $\mathrm{CeO}_{2}-\mathrm{ZrO}_{2}-\mathrm{La}_{2} \mathrm{O}_{3}-\mathrm{PrO}_{2}-\mathrm{Al}_{2} \mathrm{O}_{3}$, was synthesized by a co-precipitation method, and the supported monolith catalysts, Pd-Rh, Pt-Rh, and Pt-Pd-Rh, were obtained through an impregnation route. Of the three catalysts investigated, the Pt-Pd-Rh catalyst showed the best redox properties and the most effective oxygen storage capacity. Furthermore, the A/F, SV, and temperature characteristics for the Pt-Pd-Rh catalyst were the most superior. It is concluded that the new composite material is suitable as a motorcycle exhaust catalyst and can meet future environmental emission standards.

\section{References}

[1] Xin Q, Lin L W. Chin J Catal (辛勤, 林励吾. 催化学报), 2013, 34: 401

[2] China Vehicle Emission Control Annual Report. Ministry of Environmental Protection of the People's Republic of China. Beijing (中 国机动车污染防治年报. 中华人民共和国环境保护部. 北京), 2012

[3] Twigg M V.Appl Catal B, 2007, 70: 2

[4] Johnson T. SAE Int J Engines, 2013, 6: 699

[5] Hu C M, Zhao M, Wang H R, Chen S H, Gong M C, Shi Z H, Chen Y Q. Chin J Catal (胡春明, 赵明, 王海蓉, 陈山虎, 龚茂初, 史忠华, 陈 耀强. 催化学报), 2008, 29: 677

[6] Yan F W, Xia X K, Zou B, Hou X J. J Wuhan Univ Technol (Information Manag Eng) (颜伏伍, 夏晓坤, 邹斌, 侯献军. 武汉理工大 学学报(信息与管理工程版)), 2009, 31: 429

[7] Trade Reports. Committee of Motor Vehicle Pollution Prevention and Control, CAEPI. Beijing (行业综述. 中国环境保护产业协会机 动车污染防治委员会. 北京), 2010.38

[8] Zhang Z Q, Huan Y F, He X K, Zhao Y K. Precious Metals (张振强, 桓 源峰, 贺小昆, 赵云昆. 贵金属), 2008, 29:59

[9] Zhang H P, Liu H C.J Energy Chem, 2013, 22: 98

[10] Sheng Y Q, Zhou Y, Lu H F, Zhang Z K, Chen Y F. Chin J Catal (盛叶 琴, 周瑛, 卢晗锋, 张泽凯, 陈银飞. 催化学报), 2013, 34: 567

[11] Daturi M, Finocchio E, Binet C, Lavalley J C, Fally F, Perrichon V, Vidal H, Hickey N, Kaspar J. J Phys Chem B, 2000, 104: 9186

[12] Rainer D R, Koranne M, Vesecky S M, Goodman D W. J Phys Chem B, 1997, 101: 10769

[13] Shang H Y, Wang Y, Gong M C, Chen Y Q. J Nat Gas Chem, 2012, 21: 393

[14] Morikawa A, Suzuki T, Kanazawa T, Kikuta K, Suda A, Shinjo H. Appl Catal B, 2008, 78: 210

[15] Wang B, Wu X D, Ran R, Si Z C, Weng D. Sci Sin Chim (王斌, 吴晓东, 申锐, 司知蚌, 翁端. 中国科学化学), 2012, 42: 1315

[16] Anatoly B I, Nunan J G. US Patent 6387338. 2002

[17] Wang Q Y, Li G F, Zhao B, Zhou R X. Fuel, 2011, 90: 3047

[18] Cui Y J, He S N, Fang R M, Shi Z H, Gong M C, Chen Y Q. Chin J Catal (崔亚娟, 何胜楠, 方瑞梅, 史忠华, 龚茂初, 陈耀强. 催化学报), 2012, 33: 1020

[19] Nagai Y, Hirabayashi T, Dohmae K, Takagi N, Minami T, Shinjoh H, Matsumoto S. J Catal, 2006, 242: 103

[20] Wang G, You R, Meng M. Fuel, 2013, 103: 799

[21] Fang R M, He S N, Cui Y J, Shi Z H, Gong M C, Chen Y Q. Chin J Catal (方瑞梅, 何胜楠, 崔亚娟, 史忠华, 龚茂初, 陈耀强. 催化学报), 2012, 33: 1014

[22] Wang Q Y, Li G F, Zhao B, Zhou R X. Appl Catal B, 2010, 100: 516

[23] Leofanti G, Padovan M, Tozzola G, Venturell B. Catal Today, 1998, 41: 207 


\title{
Graphical Abstract
}

Chin. J. Catal., 2014, 35: 1482-1491 doi: 10.1016/S1872-2067(14)60092-9

\section{A new monolithic Pt-Pd-Rh motorcycle exhaust catalyst to meet future emission standards}

Suning Wang, Yajuan Cui, Li Lan, Zhonghua Shi, Ming Zhao, Maochu Gong, Ruimei Fang, Sijie Chen, Yaoqiang Chen* Sichuan University
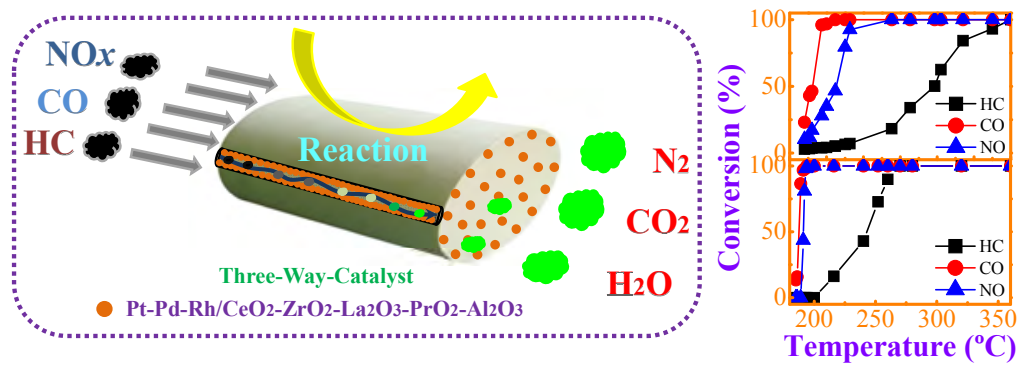

A new composite oxide, $\mathrm{CeO}_{2}-\mathrm{ZrO}_{2}-\mathrm{La}_{2} \mathrm{O}_{3}-\mathrm{PrO}_{2}-\mathrm{Al}_{2} \mathrm{O}_{3}$, was successfully synthesized by co-precipitation, and the supported monolith $\mathrm{Pd}-\mathrm{Rh}, \mathrm{Pt}-\mathrm{Rh}$, and Pt-Pd-Rh catalysts were obtained through an impregnation route. The Pt-Pd-Rh catalyst delivers outstanding performance and is suitable as a motorcycle exhaust gas catalyst that can meet future emission standards.

[24] Mattos L V, de Oliveira E R, Resende P D, Noronha F B, Passos F B. Catal Today, 2002, 77: 245

[25] Cai L, Zhao M, Pi Z, Gong M C, Chen Y Q. Chin J Catal (蔡黎, 赵明, 皮展, 龚茂初, 陈耀强. 催化学报), 2008, 29: 108

[26] Mattos L V, Noronha F B. J Power Sources, 2005, 145: 10

[27] Guo J X, Shi Z H, Wu D D, Yin H Q, Gong M C, Chen Y Q. Appl Surf Sci, 2013, 273: 527

[28] Jenog J W, Choi B C. JSME Int J, Ser B, 2002, 45: 392

[29] Huang P, Jiang H X, Zhang M H. J Rare Earths, 2012, 30: 524
[30] Weng X L, Perston B, Wang X Z, Abrahams I, Lin T, Yang S F, Evans J R G, Morgan D J, Carley A F, Bowker M, Knowles J C, Rehman I, Darr J A. Appl Catal B, 2009, 90: 405

[31] Chuang C C, Hsiang H I, Hwang J S, Wang T S. J Alloys Compd, 2009, 470: 387

[32] Fernandes D M, Scofield C F, Neto A A, Cardoso M J B, Zotin F M Z. Chem Eng J, 2010, 160: 85

[33] Zotin F M Z, da Fonseca Martins Gomes O, de Oliveira C H, Neto A A, Cardoso M J B. Catal Today, 2005, 107-108: 157

\section{一个新的满足未来排放标准的摩托车尾气净化催化剂}

\author{
王苏宁 ${ }^{\mathrm{a}}$ ，崔亚娟 ${ }^{\mathrm{b}}$ ，兰 丽 $^{\mathrm{b}}$ ，史忠华 ${ }^{\mathrm{b}}$ ，赵 明 ${ }^{\mathrm{b}}$ ，龚茂初 ${ }^{\mathrm{b}}$ ，方瑞梅 ${ }^{\mathrm{a}}$ ，陈思洁 ${ }^{\mathrm{b}}$ ，陈耀强, ${ }^{\mathrm{a},{ }^{*}}$ \\ ${ }^{\mathrm{a}}$ 四川大学化学工程学院, 四川成都610064 \\ ${ }^{\mathrm{b}}$ 四川大学化学学院, 教育部绿色化学与技术重点实验室, 四川成都6100647
}

\begin{abstract}
摘要: 采用共沉淀法制备 $\mathrm{CeO}_{2}-\mathrm{ZrO}_{2}-\mathrm{La}_{2} \mathrm{O}_{3}-\mathrm{PrO}_{2}-\mathrm{Al}_{2} \mathrm{O}_{3}$ 复合氧化物载体材料, 以浸渍法制备了 Pd-Rh, Pt-Rh和Pt-Pd- $\mathrm{Rh}$ 型整体式催 化剂. 用 $\mathrm{N}_{2}$ 吸附-脱附、程序升温还原、储氧量和 X射线衍射对其进行了表征, 并考察了老化前后催化剂的空燃比特性、空速特性 和温度特性. 结果表明, 在三种催化剂中, Pt-Pd-Rh型催化剂表现出更优异的性能. 在 $40000 \mathrm{~h}^{-1}$ 空速下, 新鲜Pt-Pd-Rh型催化剂对 $\mathrm{C}_{3} \mathrm{H}_{8}, \mathrm{CO}$ 和 $N O$ 的起燃温度 $T_{50}$ 分别为 239,187 和 $191{ }^{\circ} \mathrm{C}, \Delta T\left(T_{90}-T_{50}\right)$ 分别为 21,3 和 $3{ }^{\circ} \mathrm{C}$. 老化后, $\mathrm{C}_{3} \mathrm{H}_{8}, \mathrm{CO}$ 和 $N O$ 的 $T_{50}$ 分别为 298 , 203 和 $223{ }^{\circ} \mathrm{C}, \Delta T$ 分别为 22,5 和 $13{ }^{\circ} \mathrm{C}$, 且老化前后空燃比窗口较宽, 适合于未来排放标准的摩托车尾气净化.
\end{abstract}

关键词: 摩托车尾气净化; 整体式催化剂; 铂-钯-铑; 空燃比特性; 空速特性; 温度特性

收稿日期: 2014-01-26. 接受日期: 2014-03-21. 出版日期: 2014-09-20.

*通讯联系人. 电话/传真: (028)85418451; 电子信箱: nic7501@scu.edu.cn

基金来源：国家自然科学基金(20803049,21173153).

本文的英文电子版由Elsevier出版社在ScienceDirect上出版(http://www.sciencedirect.com/science/journal/18722067).

\section{1. 前言}

2010 年我国的摩托车年产量为 2500 万辆, 占世界总 年产量的 $40 \%$ 以上; 摩托车保有量为 1 亿辆, 占世界总保 有量的 $50 \%$ 以上 ${ }^{[1]}$. 中国已成为世界上最大的摩托车生
产大国和使用大国. 据统计, 2011年我国摩托车尾气中 的碳氢化合物 $(\mathrm{HC}) 、 \mathrm{CO}$ 和氮氧化合物 $\left(\mathrm{NO}_{x}\right)$ 的年排放量 已达 748 万吨 ${ }^{[2]}$; 此外, 与汽油车和柴油车相比, 摩托车 尾气中PM 2.5 的尺度仅为 $0.04 \mu \mathrm{m}$, 危害大, 因此摩托车 尾气净化程度的提高已刻不容缓 ${ }^{[3,4]}$. 2008年7月1日我 
国开始全面实施摩托车第III阶段排放标准 ${ }^{[5]}$, 未来摩托 车第IV阶段排放标准正在起草过程中, 将更为严格 ${ }^{[6,7]}$. 此外, 与汽车相比, 未来的摩托车即使使用电子喷射技 术控制空燃比, 依然面临着高温、高空速且空燃比波动 较大等难题 ${ }^{8]}$. 因此, 摩托车尾气要满足未来排放标准, 必须提高催化剂的性能.

摩托车尾气净化催化剂的载体材料一般由Ce-Zr储 氧材料和 $\mathrm{Al}_{2} \mathrm{O}_{3}$ 组成. 这是因为 $\mathrm{CeO}_{2}$ 与 $\mathrm{ZrO}_{2}$ 形成的固溶 体具有良好的储氧性能和可促进水-气转化反应等优点, 但抗老化和耐久性能较差 ${ }^{[9-11]}$, 而 $\mathrm{Al}_{2} \mathrm{O}_{3}$ 具有高比表面 积、大孔体积和高抗老化等优异性能 ${ }^{[12,13]}$. Morikawa 等 ${ }^{[14]}$ 研究发现, 用 $\mathrm{Al}_{2} \mathrm{O}_{3}$ 改性的 Ce- $\mathrm{Zr}$ 稀土储氧材料兼有 储氧材料和 $\mathrm{Al}_{2} \mathrm{O}_{3}$ 的共同优点, 同时 $\mathrm{Al}_{2} \mathrm{O}_{3}$ 的加入起到了 “扩散障碍” 的作用, 抑制了 $\mathrm{Ce}-\mathrm{Zr}$ 材料和贵金属的烧结 团聚. 文献 ${ }^{[15-17]}$ 报道, 在含铈氧化物中掺杂其它过渡金 属和稀土元素可改变其体相结构, 从而改善其在低温条 件下氧的传输和高温热稳定性. 摩托车尾气净化催化剂 的活性组分主要有 $P t, P d$ 和 $R h$, 通常分为单 $P d$ 型、 $P d-R h$ 型、Pt-Rh型以及Pt-Pd-Rh型催化剂 ${ }^{[18]}$.

为了将储氧材料 $(\mathrm{OSM})$ 与 $\mathrm{Al}_{2} \mathrm{O}_{3}$ 的优异性能结合起 来, 并能通过稀土元素的掺杂进一步提高载体材料的性 能, 本文采用共沉淀法制备了新型复合氧化物 $\mathrm{CeO}_{2}$ $\mathrm{ZrO}_{2}-\mathrm{La}_{2} \mathrm{O}_{3}-\mathrm{PrO}_{2}-\mathrm{Al}_{2} \mathrm{O}_{3}$, 以其作为载体制备了 $\mathrm{Pd}-\mathrm{Rh}$, $\mathrm{Pt}-\mathrm{Rh}$ 和Pt-Pd-Rh型整体式催化剂, 并结合摩托车尾气排 放特征考察了老化前后催化剂的空燃比特性、空速特性 和温度特性.

\section{2. 实验部分}

\section{1. 催化剂的制备}

采用共沉淀法制备 $\mathrm{CeO}_{2}-\mathrm{ZrO}_{2}-\mathrm{La}_{2} \mathrm{O}_{3}-\mathrm{PrO}_{2}-\mathrm{Al}_{2} \mathrm{O}_{3}$ 复 合氧化物. 按一定化学计量比称取 $\mathrm{Ce}\left(\mathrm{NO}_{3}\right)_{3} \cdot 6 \mathrm{H}_{2} \mathrm{O}$, $\mathrm{ZrO}\left(\mathrm{CO}_{3}\right) \cdot 6 \mathrm{H}_{2} \mathrm{O}, \quad \mathrm{La}\left(\mathrm{NO}_{3}\right)_{3} \cdot 6 \mathrm{H}_{2} \mathrm{O}, \quad \operatorname{Pr}\left(\mathrm{NO}_{3}\right)_{3} \cdot 6 \mathrm{H}_{2} \mathrm{O}$ 和 $\mathrm{Al}\left(\mathrm{NO}_{3}\right)_{3} \cdot 9 \mathrm{H}_{2} \mathrm{O}$, 其中 $\mathrm{ZrO}\left(\mathrm{CO}_{3}\right) \cdot 6 \mathrm{H}_{2} \mathrm{O}$ 用 $\mathrm{HNO}_{3}$ 溶解后加 入其余硝酸盐的溶液配成浓度为 $10 \%$ 的盐溶液. 以 $\mathrm{NH}_{3} \cdot \mathrm{H}_{2} \mathrm{O}$ 和 $\left(\mathrm{NH}_{4}\right)_{2} \mathrm{CO}_{3}$ 的混合溶液作沉淀剂进行滴定并 保持 $\mathrm{pH}=9$, 所得沉淀经 $90^{\circ} \mathrm{C}$ 陈化 $4 \mathrm{~h}$, 过滤, 洗涤后, 于 $70{ }^{\circ} \mathrm{C}$ 干燥, $600{ }^{\circ} \mathrm{C}$ 预分解 $3 \mathrm{~h}, 900{ }^{\circ} \mathrm{C}$ 焙烧 $5 \mathrm{~h}$, 得到质量 比为 30:10:5:5:50 的 $\mathrm{CeO}_{2}-\mathrm{ZrO}_{2}-\mathrm{La}_{2} \mathrm{O}_{3}-\mathrm{PrO}_{2}-\mathrm{Al}_{2} \mathrm{O}_{3}$ 载体材 料, 记为CZLPA.

以 CZLPA 为载体, $\mathrm{Pd}\left(\mathrm{NO}_{3}\right)_{2}, \mathrm{Pt}\left(\mathrm{NO}_{3}\right)_{4}$ 和 $\mathrm{RhCl}_{3}$ 为贵 金属前驱体, 采用等体积浸渍法制备催化剂. 首先将 $\mathrm{Pd}\left(\mathrm{NO}_{3}\right)_{2}, \mathrm{Pt}\left(\mathrm{NO}_{3}\right)_{4}$ 和 $\mathrm{RhCl}_{3}$ 分别浸渍到CZLPA上, 经干
燥后得到Pd/CZLPA, Pt/CZLPA和Rh/CZLPA三种催化 剂粉末. 然后分别将Pd/CZLPA和Rh/CZLPA催化剂粉 末, Pt/CZLPA 和 Rh/CZLPA 催化剂粉末, Pd/CZLPA, $\mathrm{Pt} / \mathrm{CZLPA}$ 和 $\mathrm{Rh} / \mathrm{CZLPA}$ 催化剂粉末加入一定量蒸馏水 进行球磨混合, 制成浆液, 取堇青石蜂窝基体(美国 Corning 公司)小样 $\left(2.5 \mathrm{~cm}^{3}\right)$ 进行涂覆, 涂覆量为 $160 \mathrm{~g} / \mathrm{L}$, 经空气吹扫, 干燥, 再于 $550{ }^{\circ} \mathrm{C}$ 焙烧 $3 \mathrm{~h}$, 得到新鲜的整体 式 $\mathrm{Pd}-\mathrm{Rh}(\mathrm{Pd} / \mathrm{Rh}=10 / 1)$ 型、 $\mathrm{Pt}-\mathrm{Rh}(\mathrm{Pt} / \mathrm{Rh}=10 / 1)$ 型和 $\mathrm{Pt}-\mathrm{Pd}-\mathrm{Rh}(\mathrm{Pt} / \mathrm{Pd} / \mathrm{Rh}=3 / 7 / 1)$ 型催化剂, 分别记为 Cat $1 \mathrm{f}$, Cat2f和Cat3f. 其中, 贵金属的涂覆量均为 $1.76 \mathrm{~g} / \mathrm{L}$.

将制得的新鲜整体式催化剂置于高温炉中, 在空气 气氛下 $1000{ }^{\circ} \mathrm{C}$ 热老化处理 $5 \mathrm{~h}$, 得到老化的 $\mathrm{Pd}-\mathrm{Rh}$ 型、 $\mathrm{Pt}-\mathrm{Rh}$ 型和Pt-Pd-Rh型催化剂, 分别记为 Cat $1 \mathrm{a}, \mathrm{Cat} 2 \mathrm{a}$ 和 Cat3a.

\section{2. 催化剂的表征}

催化剂织构性能测定在美国康塔公司SI型比表面 测定仪上进行. 首先将催化剂粉末样品于 $300^{\circ} \mathrm{C}$ 下抽真 空预处理 $3 \mathrm{~h}$, 然后以 $\mathrm{N}_{2}$ 为吸附质, 在 $-196^{\circ} \mathrm{C}$ 下进行 $\mathrm{N}_{2}$ 吸 附-脱附实验, 计算样品的比表面积、孔体积和平均孔径.

$\mathrm{H}_{2}$ 程序升温还原 $\left(\mathrm{H}_{2}-\mathrm{TPR}\right)$ 测定在自组装微型流动 反应装置上进行, 催化剂粉末样品用量为 $100 \mathrm{mg}$. 样品 先在 $\mathrm{N}_{2}$ 气流 $(20 \mathrm{~mL} / \mathrm{min})$ 中加热至 $450{ }^{\circ} \mathrm{C}$, 并保持 $50 \mathrm{~min}$, 然后降至室温, 切换到 $5 \% \mathrm{H}_{2}-95 \% \mathrm{~N}_{2}$ 混合气 $(20$ $\mathrm{mL} / \mathrm{min}$ ), 再以 $8^{\circ} \mathrm{C} / \mathrm{min}$ 的升温速率升到 $600{ }^{\circ} \mathrm{C}, \mathrm{TCD}$ 检 测耗氢量.

储氧性能(OSC)测定在自组装的实验装置上进行, 催化剂粉末样品用量 $200 \mathrm{mg}$. 样品首先在 $40 \mathrm{~mL} / \mathrm{min}$ 的 $\mathrm{H}_{2}$ 气流下升温至 $550{ }^{\circ} \mathrm{C}$, 并保持 $60 \mathrm{~min}$ 进行活化, 再切换 为 $\mathrm{He}(20 \mathrm{~mL} / \mathrm{min})$, 自然降温至 $200^{\circ} \mathrm{C}$, 脉冲注入 $\mathrm{O}_{2}$, $\mathrm{TCD}$ 检测.

$\mathrm{X}$ 射线衍射(XRD)测定在日本理学电机 $\mathrm{D} / \mathrm{max}-\mathrm{rA}$ 型 $\mathrm{X}$ 射线衍射仪上进行, 采用 $\mathrm{Cu} K_{\alpha}(\lambda=0.15406 \mathrm{~nm})$ 作为 衍射源, 管电压 $40 \mathrm{kV}$, 管电流 $25 \mathrm{~mA}$, 扫描范围 $2 \theta=$ $10^{\circ}-80^{\circ}$, 晶相与国际衍射数据中心 (ICDD) 相比较来辨 别.

\section{3. 催化剂的评价}

催化剂的评价在实验室自制的多路固定床连续流 动微型反应器中进行, 各路气体分别用质量流量计控制 进入混合器. 反应前, 催化剂在反应气氛围下于 $550^{\circ} \mathrm{C}$ 预处理 $1 \mathrm{~h}$, 然后降至反应温度进行活性评价. 其中, 空 燃比特性于温度为 $400{ }^{\circ} \mathrm{C}$, 空速为 $40000 \mathrm{~h}^{-1}$ 条件下测定; 空速特性于温度为 $400^{\circ} \mathrm{C}$, 空速为 20000,40000 和 60000 
$\mathrm{h}^{-1}$ 条件下测定; 温度特性在空速为 $40000 \mathrm{~h}^{-1}$ 条件下降 温测定. 反应气为摩托车尾气模拟气, 组成为 $0.045 \%$ $\mathrm{C}_{3} \mathrm{H}_{8}, 1.5 \% \mathrm{CO}, 0.11 \% \mathrm{NO}, 10 \% \mathrm{H}_{2} \mathrm{O}, 10 \% \mathrm{CO}_{2}$ 和不同含 量的 $\mathrm{O}_{2}$, 以 $\mathrm{N}_{2}$ 为平衡气. 采用FGA-4100型汽车排气分析 仪(佛分环保仪器检测设备制造有限公司)分析反应前后 尾气中各组分的含量, 计算各组分的转化率.

\section{3. 结果与讨论}

\section{1. 催化剂的织构性能}

表1为新鲜和老化催化剂的织构参数. 由表可见, 三 种催化剂的织构性能相近. 与新鲜催化剂相比, 老化后 催化剂的比表面积和孔体积下降, 平均孔径增大, 表明 老化后催化剂中的小孔因内聚力较大, 烧结坍塌融聚到 一起而形成大孔 ${ }^{[5,19]}$. 老化后催化剂的比表面积仍有 70 $\mathrm{m}^{2} / \mathrm{g}$ 左右, 略高于文献值 ${ }^{[14,20]}$, 说明以新型复合氧化物载 体材料CZLPA负载的催化剂具有较好的抗高温老化能 力, 适合摩托车尾气的高温环境.

图 1 为新鲜和老化催化剂的 $\mathrm{N}_{2}$ 吸附-脱附等温线和 孔径分布. 可以看出, 新鲜催化剂的孔径集中在 $4-8 \mathrm{~nm}$, 各催化剂样品的吸脱附曲线均表现出典型的 IV 型等温 线和 $\mathrm{H}_{2}$ 型滞后环, 说明样品的孔为狭缝型和墨水瓶型的 介孔. 介孔越大, 毛细管凝聚发生的压力越高, 所以高压 区吸附量上升较快, 说明大孔较多 ${ }^{[21,22]}$, 适合摩托车尾 气的高空速环境. 老化后, 孔径集中在 5-12 nm, 向大孔 方向移动, 而且回滞环面积有不同程度的收缩, 这进一 步说明老化后小孔坞塌, 孔径变大 ${ }^{[19,23]}$. 同时, Pd-Rh型 和 $\mathrm{Pt}-\mathrm{Rh}$ 型催化剂的回滞环均在相对压力 $\left(p / p_{0}\right)$ 为 0.8 左 右开始闭合, 比新鲜催化剂增大了 $23 \%$, 而Pt-Pd-Rh型催 化剂的回滞环在 $p / p_{0}=0.7$ 左右开始闭合, 比新鲜催化剂 仅增大了 $7.7 \%$, 说明Pt-Pd-Rh型催化剂小孔坞塌程度较 小, 抗高温老化能力更优 ${ }^{[23]}$.

\section{2. $\mathrm{H}_{2}$-TPR结果}

图2为新鲜和老化催化剂的 $\mathrm{H}_{2}-\mathrm{TPR}$ 谱. 由图可见, 新鲜催化剂和老化催化剂的还原峰温均在 $400{ }^{\circ} \mathrm{C}$ 以下, 归属为贵金属 $\mathrm{Pd}, \mathrm{Pt}$ 和 $\mathrm{Rh}$ 的还原峰 ${ }^{[24-27]}$, 且相比于文 献 ${ }^{[24-27]}$ 中以 Ce 基材料为载体的贵金属催化剂, 还原峰温 向低温偏移, 说明本文制备的催化剂具有较好的还原性 能. 与新鲜催化剂相比, 老化后样品的还原峰面积有所 下降. 这是由于贵金属在载体表面发生团聚、烧结, 加之 载体材料的比表面积和孔体积下降, 使得一部分贵金属 物种被包裹掩埋, 造成可还原物种量减少所致 ${ }^{[21,28]}$. 老 化前后, 三种催化剂的还原峰面积大小为Pt-Pd-Rh >
Pd-Rh $>$ Pt-Rh, 可见Pt-Pd-Rh型催化剂还原性能较好.

\subsection{OSC 结果}

图3为新鲜和老化催化剂的储氧量. 由图可见, 与新 鲜催化剂相比, 老化后三种催化剂的储氧量均有所下降, 主要是由于载体材料的烧结和贵金属的团聚所致 ${ }^{[14,27]}$. 其中, 老化前后Pt-Pd-Rh型催化剂的储氧量最高, Pt-Rh 型催化剂的最低. 这可能是各贵金属元素与载体材料的 结合能力和贵金属之间的协同作用不同的结果 ${ }^{[28]}$. 由 此可见本文制备的Pt-Pd-Rh型催化剂适合于空燃比波动 较大且长期高温的摩托车尾气环境.

\subsection{XRD结果}

图4是新鲜和老化催化剂的XRD谱. 可以看出, 新 鲜和老化催化剂均为典型的立方结构 $\mathrm{Ce}_{0.75} \mathrm{Zr}_{0.25} \mathrm{O}_{2}$ 相, 空间群为 Fm-3m. 相对于 Fm-3m结构的 $\mathrm{Ce}_{0.75} \mathrm{Zr}_{0.25} \mathrm{O}_{2}$ 标 准谱, 谱峰向小角度偏移, 这可能是载体材料中掺杂的 原子半径较大的稀土元素 $\mathrm{La}\left(\gamma_{\mathrm{La}}{ }^{3+}=0.106 \mathrm{~nm}\right)$ 和 $\operatorname{Pr}\left(\gamma_{\mathrm{Pr}^{3+}}\right.$ $\left.=0.101 \mathrm{~nm}, \gamma_{\mathrm{Pr}^{4+}}=0.09 \mathrm{~nm}\right)$ 进入到 $\mathrm{Ce}_{0.75} \mathrm{Zr}_{0.25} \mathrm{O}_{2}$ 晶格 $\left(\gamma_{\mathrm{Ce}^{4+}}=0.097 \mathrm{~nm}, \gamma_{\mathrm{Zr}^{4+}}=0.084 \mathrm{~nm}\right)$ 的结果 ${ }^{[17,22]}$. 老化后, 各催化剂的衍射峰变得强而尖锐, 并检测到 $\gamma-\mathrm{Al}_{2} \mathrm{O}_{3}$ 的衍 射峰, 表明高温焙烧导致晶粒长大, 晶型趋于完整. 另 外, 老化后三种催化剂的衍射峰向大角度偏移, 这是由 于半径较大的 $\mathrm{La}^{3+}, \mathrm{Pr}^{3+} / \mathrm{Pr}^{4+}$ 由体相向表面迁移, 同时高 温焙烧后 $\mathrm{Ce}^{3+}\left(\gamma_{\mathrm{Ce}^{3+}}=0.114 \mathrm{~nm}\right)$ 向 $\mathrm{Ce}^{4+}$ 转化, 造成晶胞收 缩 ${ }^{[17,22,29,30]}$.

根据Scherrer公式计算得老化前后催化剂平均晶粒 尺寸均在 5.5-7.5 nm, 即老化后催化剂的平均晶粒尺寸 变化不大, 说明催化剂的热稳定性能较好. 这可能得益 于 $\mathrm{Al}_{2} \mathrm{O}_{3}$ 在材料中充当了 “扩散障碍” 的分散物质, 限制 了载体材料之间的相互接触, 从而在一定程度上抑制了 载体材料颗粒的团聚长大, 增加了材料的热稳定性 ${ }^{[14,31]}$.

\section{5. 催化剂的空燃比特性}

图5 是新鲜和老化的催化剂在 $40000 \mathrm{~h}^{-1}$ 空速条件下 的空燃比特性, 即 $\mathrm{C}_{3} \mathrm{H}_{8}, \mathrm{CO}$ 和 $\mathrm{NO}$ 转化率与空燃比 $S$ 的关 系曲线. 对于新鲜催化剂, 在富燃区 $(S<1)$, 三种催化剂 均能使 $\mathrm{NO}$ 达到完全转化, 并使得 $\mathrm{CO}$ 转化率达到 $80 \%$ 以 上, 但Pd-Rh型和Pt-Pd- $\mathrm{Rh}$ 型更有利于 $\mathrm{C}_{3} \mathrm{H}_{8}$ 的转化, 这可 能是由于富燃时 $\mathrm{Pd}-\mathrm{Rh}$ 型和Pt-Pd-Rh型催化剂上更有利 发生 $\mathrm{C}_{3} \mathrm{H}_{8}$ 的蒸汽重整反应 ${ }^{[17,18,22]}$. 在贫燃区 $(S>1)$, 随着 $S$ 值的增大, 三种催化剂均能催化氧化CO达到完全转化, 而NO的转化率则急剧下降, 并且 $\mathrm{Pd}-\mathrm{Rh}$ 型催化剂的 NO 窗口明显窄于其它两类催化剂. 这是由于 $\mathrm{NO}$ 受 $\mathrm{O}_{2}$ 浓度 的影响, 还原反应受到限制. 同时, Pt-Rh和Pt-Pd-Rh型催 
化剂上 $\mathrm{C}_{3} \mathrm{H}_{8}$ 的转化率随着 $S$ 值的增大有所下降, 而Pd-Rh 型催化剂上的 $\mathrm{C}_{3} \mathrm{H}_{8}$ 仍然可以达到完全转化, 这可能是由 于Pt-Rh和Pt-Pd-Rh型催化剂上 $\mathrm{C}_{3} \mathrm{H}_{8}$ 和 $N O$ 的偶联反应更 为明显. 与新鲜催化剂比较, 老化后的催化剂对三种污 染物的转化能力均下降. 主要原因是高温老化过程中, 小孔埋塌, 比表面积下降, 贵金属烧结, 活性位点减少, 催化反应受限 ${ }^{[19,27]}$. 这与老化后催化剂的织构性能下降 相一致. 图5(c)汇总了三种催化剂在 $40000 \mathrm{~h}^{-1}$ 空速下老 化前后空燃比窗口的宽度. 由图可见, 新鲜催化剂的空 燃比窗口宽度顺序为Pt-Pd-Rh $>$ Pd-Rh $>$ Pt-Rh; 老化后, 三种催化剂空燃比窗口宽度均有所下降, 下降程度顺序 为 $\mathrm{Pt}-\mathrm{Rh}>\mathrm{Pd}-\mathrm{Rh}>\mathrm{Pt}-\mathrm{Pd}-\mathrm{Rh}$. 这表明Pt-Pd-Rh催化剂的 空燃比性能及抗老化性能优异. 这与TPR和OSC结果相 一致.

\section{6. 催化剂的空速特性}

图6为新鲜催化剂在 20000 和 $60000 \mathrm{~h}^{-1}$ 空速下的空 燃比窗口. 结合图 5(a)和(c)可见, 随着空速的增大, 催化 剂空燃比窗口不同程度变窄. 这是由于空速增大, 气体 在催化剂上停留时间变短, 传质受到限制, 甚至反应物 来不及进入催化剂孔道进行反应所致. 可以发现, Pt-Pd-Rh型催化剂在 20000,40000 和 $60000 \mathrm{~h}^{-1}$ 空速下的 空燃比窗口最宽, 空速特性最好, 更适合于摩托车尾气 的高空速环境.

\section{7. 催化剂的温度特性}

图7是新鲜和老化催化剂在 $40000 \mathrm{~h}^{-1}$ 空速下模拟摩
托车尾气中 $\mathrm{C}_{3} \mathrm{H}_{8}, \mathrm{CO}$ 和 $\mathrm{NO}$ 转化率随温度的变化曲线. 三种污染物对应的起燃温度 $T_{50}$ (转化率达 $50 \%$ 时的温 度)、完全转化温度 $T_{90}$ (转化率达 $90 \%$ 时的温度)和 $\Delta T\left(T_{90}\right.$ 与 $T_{50}$ 的差值)列于表 2 . 由图7可知, 对于新鲜和老化催化 剂, 随着温度的升高, $\mathrm{C}_{3} \mathrm{H}_{8}, \mathrm{CO}$ 和 $\mathrm{NO}$ 的转化率升高, 并 可以迅速达到完全转化. 其中, $\mathrm{Pt}-\mathrm{Rh}$ 型催化剂对 $\mathrm{C}_{3} \mathrm{H}_{8}$ 的 起燃温度和完全转化温度最低, 这是因为贵金属Pt对饱 和烃的转化较好 ${ }^{[24,32]}$. 老化后, 各催化剂的 $T_{50}, T_{90}$ 和 $\Delta T$ 都有所升高, 而以 $\mathrm{Pt}-\mathrm{Rh}$ 型催化剂最为明显. 这主要是由 于老化后, 载体材料坞塌烧结, 贵金属团聚, 造成表面活 性位数量下降, 因而催化剂活性下降 ${ }^{[32,33]}$. CO 与 $N O$ 的 $T_{50}$ 和 $T_{90}$ 都相对较低, 这是因为摩托车尾气中 $\mathrm{CO}$ 含量相 对汽车较高, 一经起然, $\mathrm{CO}$ 反应热导致尾气温度骤升, 所以很快就达到完全转化. 此外, $\mathrm{CO}$ 和 $\mathrm{NO}$ 的 $T_{50}$ 相差较 小, 说明 $\mathrm{CO}$ 和 $\mathrm{NO}$ 二者耦合较好. 综合老化前后三种污 染物的 $T_{50}, T_{90}$ 和 $\Delta T$, 以 Pt-Pd-Rh型催化剂的性能最优, 与表征结果一致.

\section{4. 结论}

采用共沉淀法制备了新型复合氧化物材料 $\mathrm{CeO}_{2}$ $\mathrm{ZrO}_{2}-\mathrm{La}_{2} \mathrm{O}_{3}-\mathrm{PrO}_{2}-\mathrm{Al}_{2} \mathrm{O}_{3}$, 并以此为载体制备了 $\mathrm{Pd}-\mathrm{Rh}$, Pt-Rh和Pt-Pd-Rh型催化剂. 三种催化剂中, Pt-Pd-Rh型 催化剂在老化前后还原性能和储氧量最优, 空燃比特 性、空速特性及温度特性最优, 适合于未来摩托车尾气 排放标准催化剂的需求. 